\title{
Anterior QRS forces in posterolateral infarction
}

\author{
P. Toutouzas, A. Koidakis, P. Papadopoulos and D. Avgoustakis \\ From the Department of Cardiology, Medical School of the University of Athens; Hippocration Hospital, \\ Athens, Greece
}

The $Q R S$ loop on the horizontal plane of the vectorcardiogram and the $Q R S$ complex in the right praecordial leads of the electrocardiogram were studied in 80 patients with strictly posterior and/or lateral infarction.

In all 30 patients with combined posterolateral infarction a ratio $R / S$ greater than $I$ in lead $V I$ was found. In 19 out of the 23 patients with strictly posterior infarction and in all 9 patients with isolated lateral infarction this ratio was less than I. Posteroinferior infarction ( 18 patients) behaved like strictly posterior infarction.

In posterolateral infarction a pronounced preponderance of the anterior over the posterior $Q R S$ loop forces was noted. The $0.02 \mathrm{sec}$ vector was oriented anteriorly and to the right. In strictly posterior infarction the preponderance of the anterior over posterior $Q R S$ forces was not so great and the $0.02 \mathrm{sec}$ vector was oriented to the left; the $0.04 \mathrm{sec}$ and maximal $Q R S$ vectors were located anteriorly and to the left but in a more leftward orientation as compared to the corresponding vectors in posterolateral infarction. In isolated lateral infarction the $0.02 \mathrm{sec}$ vector was always anteriorly and to the right, but the $0.04 \mathrm{sec}$ and maximal $Q R S$ vectors were oriented posteriorly.

$A$ possible mechanism of the appearance of the tall $R$ wave in $V_{I}$ in posterolateral infarction is discussed.

Electrocardiographic diagnostic criteria of posterior myocardial infarction are inadequate. The posterior necrosis changes the orientation of the electrical forces anteriorly. In the praecordial leads $V_{4} R$ and/ or VI the ratio $R / S$ is greater than or equal to $I$ (Lipman and Massie, I965). This ratio in lead VI is the main electrocardiographic feature of the posterior myocardial infarction (Massie and Walsh, 1960; Perloff, 1964; Hoffman et al., 1965; Tandowsky, I968).

Since, however, in posterior infarction the mean vector shifts anteriorly in the horizontal plane, maintaining the counterclockwise rotation, the vectorcardiogram offers diagnostic advantages (Hugenholtz, Forkner, and Levine, 1961; Gray et al., 1972).

In a previous study in ro patients with true posterior infarction we had noticed the frequent absence of the suggested typical electrocardiographic criteria (Toutouzas et al., 1969). On the contrary, the vectorcardiogram showed a strictly posterior myocardial infarction in all the cases. Similar findings have been reported by Gray et al. (1972).

The above observations give rise to doubts concerning the diagnostic capabilities of the electro-

Received 13 June 1973. cardiogram in cases of true posterior myocardial infarction. Moreover, as is well known, a prominent $R$ wave in VI has been described in cases of lateral (Pruitt, Dennis, and Kinard, 1963) as well as posterolateral infarction of the left ventricle (Levy et al., 1950; Tulloch, 1952; World Health Organization, 1959).

In this study the influence of infarcts involving the posterior and the lateral wall of the left ventricle on the various segments of the vectorcardiographic QRS loop, as well as on the QRS complex of the right praecordial electrocardiographic leads, are investigated.

\section{Subject and methods}

Studies were made in 80 patients with myocardial infarction. Ten of these patients were admitted to the Cardiovascular Research Unit at Hammersmith Hospital and 70 to the Department of Cardiology of the University of Athens. Sixty-nine were men and II were women, 35 to 78 years of age (average 54 years).

The diagnosis of infarction was based on the clinical picture, the raised level of serum enzymes, the electrocardiogram, and the vectorcardiogram. The present observations were carried out 2 weeks to 3 years after the attack.

Cases with right or left bundle-branch block on the electrocardiogram as well as cases presenting clinical or 
radiological evidence of right ventricular hypertrophy were excluded.

The patients were divided into 4 groups according to the vectorcardiographic and electrocardiographic location of the infarction.

Group I: Posterior infarction (23 patients).

Group II: Posteroinferior infarction (I8 patients).

Group III: Posterolateral infarction with or without extension to the inferior wall ( 30 patients).

Group IV: Lateral or inferolateral infarction (9 patients).

The diagnosis of true posterior infarction was made by the vectorcardiogram alone. The following diagnostic criteria were applied.

a) Prominence of the anterior forces of the QRS loop, over the posterior ones, both in voltage and duration (Hugenholtz et al., 196r; Gunnar et al., 1967; Tandowsky, 1968).

b) Configuration and orientation changes of the second half of the QRS loop (Walsh et al., 1962; Hoffman et al., 1965).

c) Delay of the terminal QRS forces (Tranchesi et al., 196I; Toutouzas et al., 1969; Gunnar et al., 1970).

The criteria for posteroinferior infarction were as follows.

a) The vectorcardiographic diagnostic criteria of posterior infarction.

b) Superior deviation of the $0.025 \mathrm{sec}$ vector in association with a clockwise rotation of the initial QRS loop forces in the frontal plane (Massie and Walsh, 1960; Hugenholtz et al., 1961).

c) Appearance of a $Q$ wave in leads II and VF of the electrocardiogram, with an amplitude at least 25 per cent that of the following $R$ wave and duration equal to or longer than $0.04 \mathrm{sec}$ (Myers and Oren, 1945; Goldberger, 1953; Friedberg, 1966).

Inferolateral infarction was diagnosed on the basis of the criteria used for the inferior wall infarction, plus the appearance of an abnormal $Q$ wave in leads $I, a V L, V_{5}$, V6, and/or a right orientation of the initial QRS loop forces ranged over $22 \mathrm{msec}$ (Walsh et al., I962; Chou and Helm, 1967).

Vectorcardiograms were recorded on a HewlettPackard I520A apparatus in 70 patients and on a Cambridge multichannel recorder in to patients using the Frank lead system (Frank, 1956).

Special attention was paid to the horizontal plane on which the following measurements of the QRS loop were made.

I) The orientation (in degrees) and the voltage (in $\mathrm{mV}$ ) of the maximal vector of the QRS loop.

2) The orientation of the instantaneous vectors 0.02 , 0.04 , and $0.06 \mathrm{sec}$.

3) The duration (msec) of the right deviation of the initial forces of the QRS loop.

4) The duration of the anterior and posterior $Q R S$ forces and the maximal anterior and maximal posterior voltage of these forces.

5) The rotation of the QRS loop.

6) The delay in recording the terminal forces of the QRS loop.

The electrocardiograms taken on the same day as the vectorcardiograms comprised the 12 conventional leads and occasionally the praecordial ones, $\mathrm{V}_{4} R$ and $V_{7}$. The ratio $R / S$ in leads VI and V2 was especially studied.

TABLE I Vectorcardiographic data derived from 80 patients: mean values and standard deviations (brackets)

\begin{tabular}{|c|c|c|c|c|c|c|c|c|c|c|c|c|}
\hline \multirow[t]{3}{*}{ Infarct groups } & \multirow{3}{*}{$\begin{array}{l}\text { No. } \\
\text { of } \\
\text { patients }\end{array}$} & \multicolumn{11}{|c|}{$Q R S$ loop in horizontal plane } \\
\hline & & \multirow[t]{2}{*}{ Rotation } & \multicolumn{2}{|c|}{ Maximal vector } & \multicolumn{3}{|c|}{$\begin{array}{l}\text { Vector orientation } \\
\text { (degrees) }\end{array}$} & \multicolumn{2}{|c|}{ Anterior forces } & \multicolumn{2}{|c|}{ Posterior forces } & \multirow{2}{*}{$\begin{array}{l}\text { Slow } \\
\text { terminal } \\
\text {-forces } \\
\text { (no. of } \\
\text { patients) }\end{array}$} \\
\hline & & & $\begin{array}{l}\text { Orien- } \\
\text { tation } \\
\text { (de- } \\
\text { grees) }\end{array}$ & $\begin{array}{l}\text { Vol- } \\
\text { tage } \\
(m V)\end{array}$ & $\begin{array}{l}0.02 \\
\sec \end{array}$ & $\begin{array}{l}0.04 \\
\sec \end{array}$ & $\begin{array}{l}0.06 \\
\sec \end{array}$ & $\begin{array}{l}\text { Dura- } \\
\text { tion } \\
\text { (msec) }\end{array}$ & $\begin{array}{l}\text { Max- } \\
\text { imum } \\
\text { anterior } \\
\text { voltage } \\
(m V)\end{array}$ & $\begin{array}{l}\text { Dura- } \\
\text { tion } \\
\text { (msec) }\end{array}$ & $\begin{array}{l}\text { Max- } \\
\text { imum } \\
\text { post- } \\
\text { erior } \\
\text { voltage } \\
(m V)\end{array}$ & \\
\hline $\begin{array}{l}\text { I: Strictly } \\
\text { posterior }\end{array}$ & 23 & $\mathrm{CCW}$ & $\begin{array}{r}+24 \cdot 3 \\
(15 \cdot 3)\end{array}$ & $\begin{array}{l}1.25 \\
(0.5)\end{array}$ & $\begin{array}{c}+62 \cdot 3 \\
(34)\end{array}$ & $\begin{array}{l}+24 \cdot 1 \\
(18 \cdot 5)\end{array}$ & $\begin{array}{c}-105 \cdot 3 \\
(160)\end{array}$ & $\begin{array}{l}45 \cdot 5 \\
(4 \cdot 5)\end{array}$ & $\begin{array}{l}0.50 \\
(0.17)\end{array}$ & $\begin{array}{l}35 \cdot 5 \\
(8 \cdot 7)\end{array}$ & $\begin{array}{l}0.33 \\
(0.11)\end{array}$ & I9 \\
\hline & 18 & CCW & $\begin{array}{l}+21 \\
(15.8)\end{array}$ & $\begin{array}{c}1 \cdot 33 \\
(0 \cdot 36)\end{array}$ & $\begin{array}{r}+60 \cdot 1 \\
(26 \cdot 2)\end{array}$ & $\begin{array}{r}+22 \cdot 5 \\
(9 \cdot 7)\end{array}$ & $\begin{array}{l}-79 \cdot 4 \\
(127)\end{array}$ & $\begin{array}{l}46 \cdot 5 \\
(6 \cdot 2)\end{array}$ & $\begin{array}{l}0.58 \\
(0.62)\end{array}$ & $\begin{array}{l}35 \cdot 2 \\
(7 \cdot 1)\end{array}$ & $\begin{array}{l}0.39 \\
(0.51)\end{array}$ & II \\
\hline $\begin{aligned} \text { III: } & \text { Postero- } \\
& \text { infero- } \\
& \text { lateral or } \\
& \text { postero- } \\
& \text { lateral }\end{aligned}$ & 30 & $\begin{array}{l}\text { CCW } \\
\text { CCW-CW }\end{array}$ & $\begin{array}{r}+49.4 \\
(25.5)\end{array}$ & $\begin{array}{l}1 \cdot 09 \\
(0 \cdot 33)\end{array}$ & $\begin{array}{r}+118 \cdot 4 \\
(20 \cdot 2)\end{array}$ & $\begin{array}{r}+39 \cdot 3 \\
(21 \cdot 1)\end{array}$ & $\begin{array}{l}-63.5 \\
(110.3)\end{array}$ & $\begin{array}{l}57 \cdot 1 \\
(9 \cdot 8)\end{array}$ & $\begin{array}{l}0.80 \\
(0.27)\end{array}$ & $\begin{array}{l}30 \cdot 8 \\
(8 \cdot 3)\end{array}$ & $\begin{array}{l}0.31 \\
(0 \cdot 25)\end{array}$ & 17 \\
\hline $\begin{array}{l}\text { IV: Lateral or } \\
\text { infero- } \\
\text { lateral }\end{array}$ & 9 & $\begin{array}{l}\text { CCW } \\
\text { CCW-CW }\end{array}$ & $\begin{array}{l}-4 \mathrm{I} \\
(20)\end{array}$ & $\begin{array}{c}1 \cdot 3 \\
(0 \cdot 39)\end{array}$ & $\begin{array}{r}+129 \\
(32)\end{array}$ & $\begin{array}{l}-48 \\
(28)\end{array}$ & $\begin{array}{l}-98 \cdot 6 \\
(33)\end{array}$ & $\begin{array}{l}3 r \cdot 5 \\
(7)\end{array}$ & $\begin{array}{c}0.38 \\
(0.10)\end{array}$ & $\begin{array}{l}50 \cdot 9 \\
(6 \cdot 2)\end{array}$ & $\begin{array}{c}0.88 \\
(0.26)\end{array}$ & 2 \\
\hline
\end{tabular}



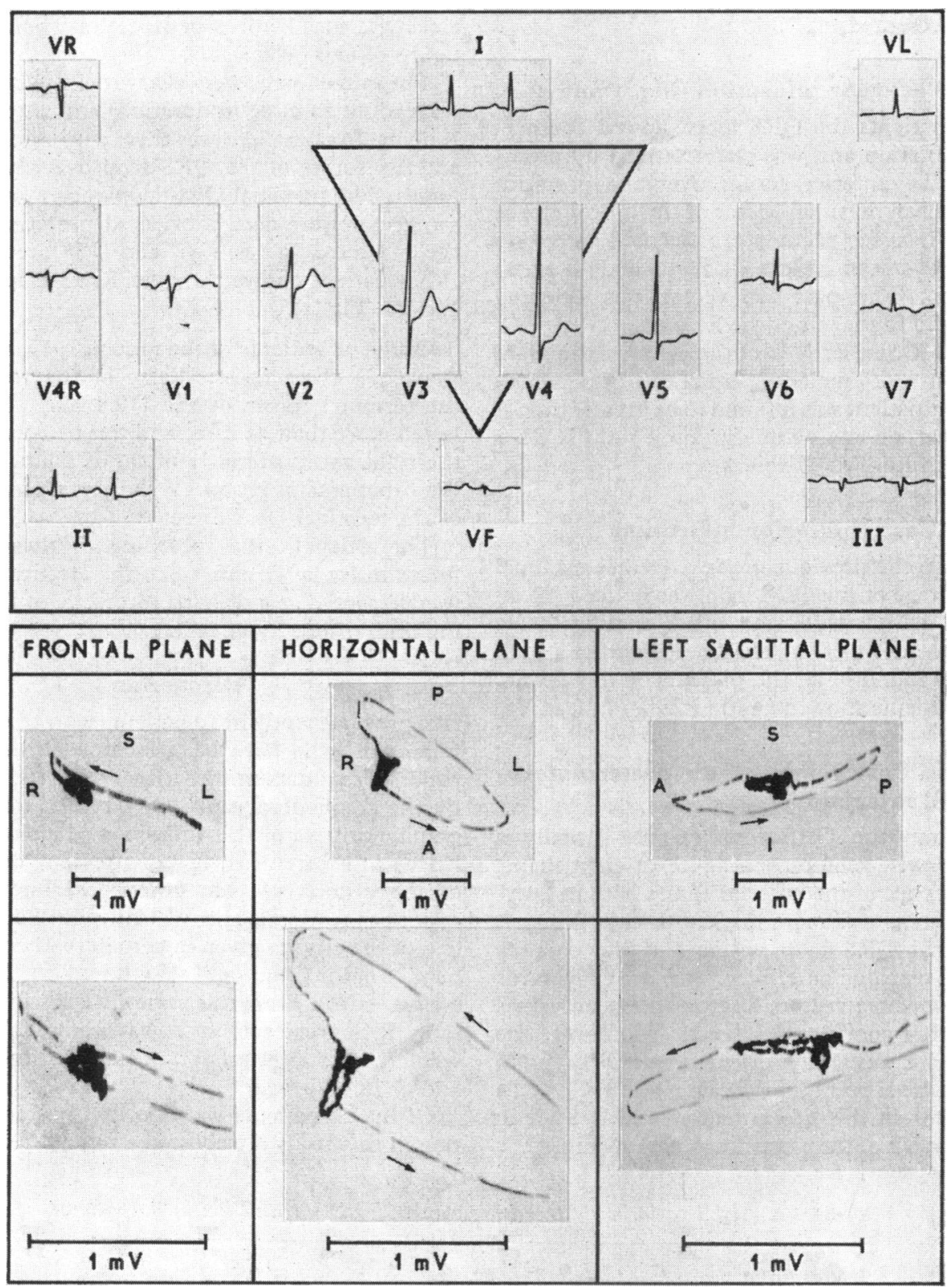

FIG. I Vectorcardiogram and electrocardiogram taken on the I5th day of acute myocardial infarction. There is anterior displacement of the QRS loop as seen in the horizontal and sagittal planes suggesting posterior infarction. The electrocardiographic changes are minimal; in VI the $R / S$ ratio is less than $I$ (reproduced from Toutouzas et al. 1969, by permission of the authors and the publisher). 


\section{Results}

The vectorcardiographic findings in the horizontal plane are presented in Table $\mathbf{r}$.

\section{Group I: Posterior infarction (Fig. I and 2)}

In all the patients the QRS loop showed counterclockwise rotation and was characterized by prominence of the anterior forces over the posterior ones. The mean maximal vector of the QRS loop, as well as the $0.04 \mathrm{sec}$ vector were oriented anteriorly in all cases (mean values $+24 \cdot 3^{\circ}$ and $+24 \cdot 1^{\circ}$, respectively). The $0.02 \mathrm{sec}$ vector was oriented anteriorly and to the left of the $E$ point.

The ratio $R / S$ in lead VI of the electrocardiogram was less than I (I9 patients), equal to I (3 patients), and only in I patient was it found to be greater than $I$. In 17 of the patients of this group a ratio $R / S>I$ was found in lead V2 (Table 2).

\section{Group II: Posteroinferior infarction}

Compared to the previous group a greater maximal anterior voltage of the QRS loop was noticed (mean value $0.58 \mathrm{mV}$ ), while the other findings were similar. In lead VI of the electrocardiogram a ratio $R / S<I$ was found in all the patients of this group. Fourteen patients showed a ratio $R / S>I$ in lead V2.

\section{Group III: Posterolateral or posteroinfero- lateral wall infarction}

In this group the QRS loop showed usually a counterclockwise rotation or a figure-of-eight shape. The prominence of the anterior forces both in duration and voltage was more marked than in group I. The maximal QRS loop vector and the $0.04 \mathrm{sec}$ vector were oriented anteriorly yet more rightwards than the respective vectors in group I (mean values $+49.4^{\circ}$ and $+39.3^{\circ}$, respectively). Moreover, the $0.02 \mathrm{sec}$ vector was always oriented anteriorly and to the right of the $\mathrm{E}$ point (mean value $+\mathrm{r} 18^{\circ} 4^{\circ}$ ).

All patients in this group had a ratio $R / S>I$ in leads VI and V2 of the electrocardiogram (Fig. 3).

\section{Group IV: Lateral or inferolateral infarction}

In this group the QRS loop rotation was counterclockwise in all but 2 patients, in whom it took a figure-of-eight shape.

The initial forces were always oriented to the right (exceeding $22 \mathrm{msec}$ in duration) and anterior of the $\mathrm{E}$ point. In no patient was there a prominence of the anterior forces of the QRS loop over the posterior forces. The maximal QRS loop vector and the 0.04 sec vector were always oriented posteriorly and to the left (mean values $-41^{\circ}$ and $-48^{\circ}$, respectively).

No patient showed a ratio $R / S>I$ in leads VI and V2 (Fig. 4).

Of the 7I patients of the groups I, II, and III, 47 showed a characteristic delay of the recording of the terminal forces of the QRS loop. This delay lasted more than $30 \mathrm{msec}$ and was usually located to the right and posteriorly of the E point. Only 2 of the 9 patients of group IV showed analogous delay of the terminal QRS forces.

The delay in the recording of these terminal forces in leads VI and V2 of the electrocardiogram was presented as a delayed recording of the ascending limb of the $\mathrm{S}$ deflection.

\section{Discussion}

In a previous study in Io patients with true posterior infarction, who have been included in the present paper (Toutouzas et al., 1969), we were impressed by the frequent absence of typical electrocardiographic criteria of this infarction. This observation led us to a careful review of previous descriptions of the criteria of true posterior infarction (Elek et al., 1954; Massie and Walsh, 1960; Perloff, 1964) and of the criteria given in certain textbooks (Friedberg, 1966; Chou and Helm, 1967; Hurst and Logue, 1970). From this review we concluded that a ratio $R / S$ greater than I was commonly present when the posterior infarction extended to the lateral and/or inferior wall.

Of the 23 patients with isolated posterior infarction in this study, I9 showed a ratio $R / S$ less than I

TABLE $2 R / S$ ratio in electrocardiographic leads $V_{I}$ and $V_{2}$ in 80 patients

\begin{tabular}{llllll}
\hline Infarct groups & \multirow{2}{*}{$\begin{array}{l}\text { No. of } \\
\text { patients }\end{array}$} & \multicolumn{1}{l}{$V_{I}$} & & $V 2$ & \\
\cline { 3 - 6 } & & $R / S \geqslant I$ & $R / S<I$ & $R / S>I$ & $R / S<I$ \\
\hline I: Strictly posterior & 23 & 4 & 19 & 17 & 6 \\
II: Posteroinferior & 18 & 0 & 18 & 14 & 4 \\
III: Posteroinferolateral & 30 & 30 & 0 & 30 & 0 \\
$\quad \begin{array}{l}\text { or posterolateral } \\
\text { IV: Lateral or } \\
\text { inferolateral }\end{array}$ & 9 & 0 & 9 & 0 & 9 \\
& & & & & \\
\hline
\end{tabular}



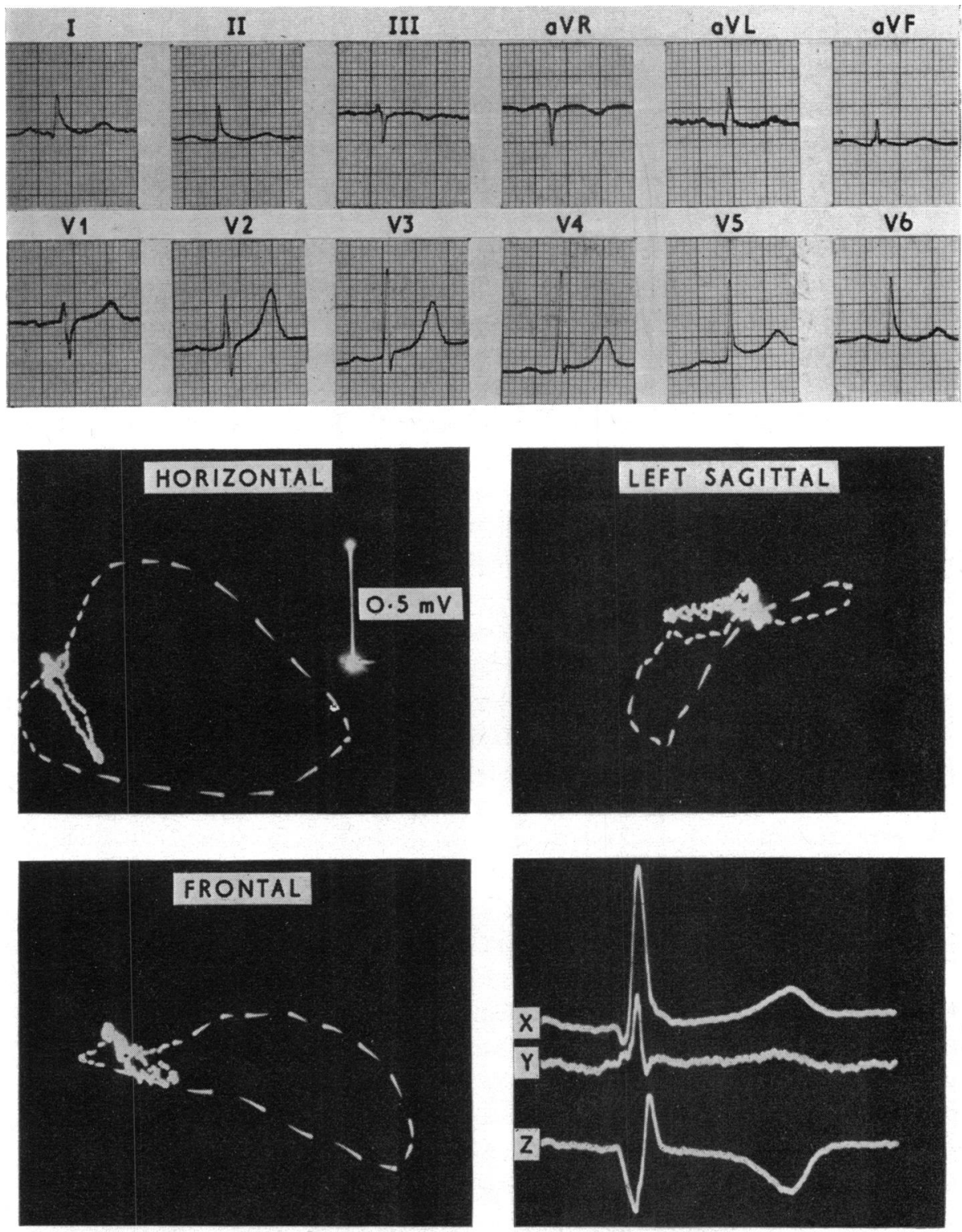

FIG. 2 Strictly posterior infarction. Ten days before the above electrocardiogram and vectorcardiogram were recorded, the patient, 49 years of age, presented the clinical picture of an acute infarction, followed by a rise in the serum enzymes. The vectorcardiogram as well as the $Z$ axis of the orthogonal electrocardiogram show a preponderance of the anterior over the posterior $Q R S$ forces; the initial $Q R S$ forces directed to the right of the $E$ point are normal. The electrocardiogram shows tall $T$ waves in $V_{I}$ to $V_{3}$; however, the ratio $R / S$ in $V_{I}$ is less than $I$. 
1250 Toutouzas, Koidakis, Papadopoulos, and Avgoustakis
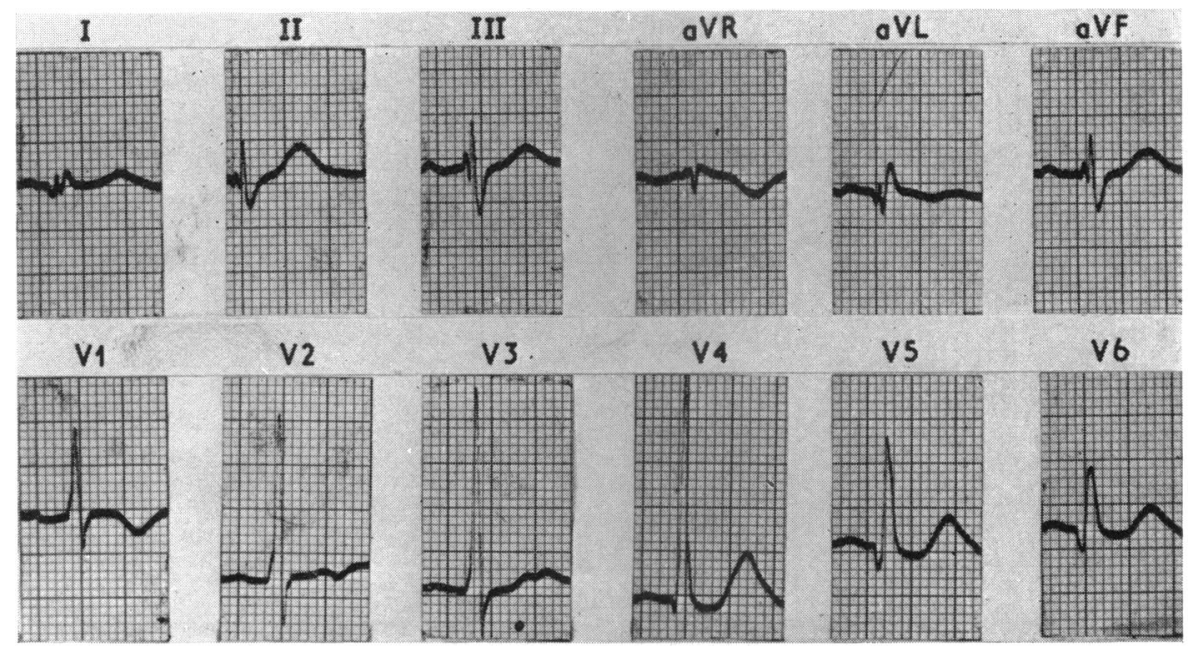

V2

v3

V4

v5

V6
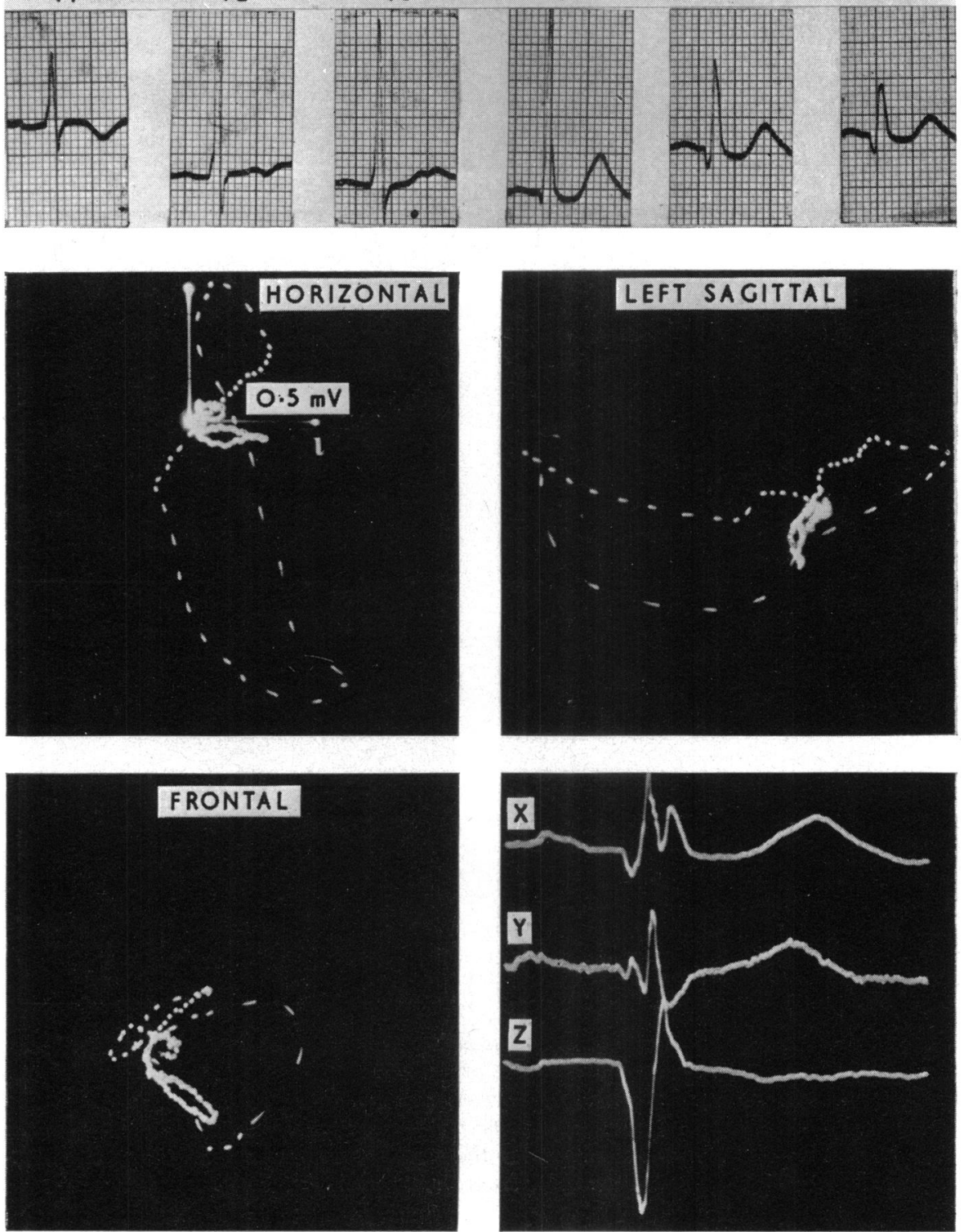

FIG. 3 Posterolateral infarction probably extended to the inferior wall. The vectorcardiogram and the $Z$ axis of the orthogonal electrocardiogram show pronounced preponderance of the anterior over the posterior $Q R S$ forces, combined with an increase of the initial forces to the right of the $E$ point. In lead $V_{I}$ the ratio $R / S$ is greater than $I$. 


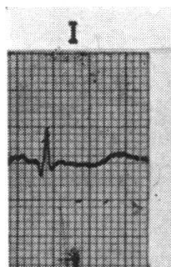

V1
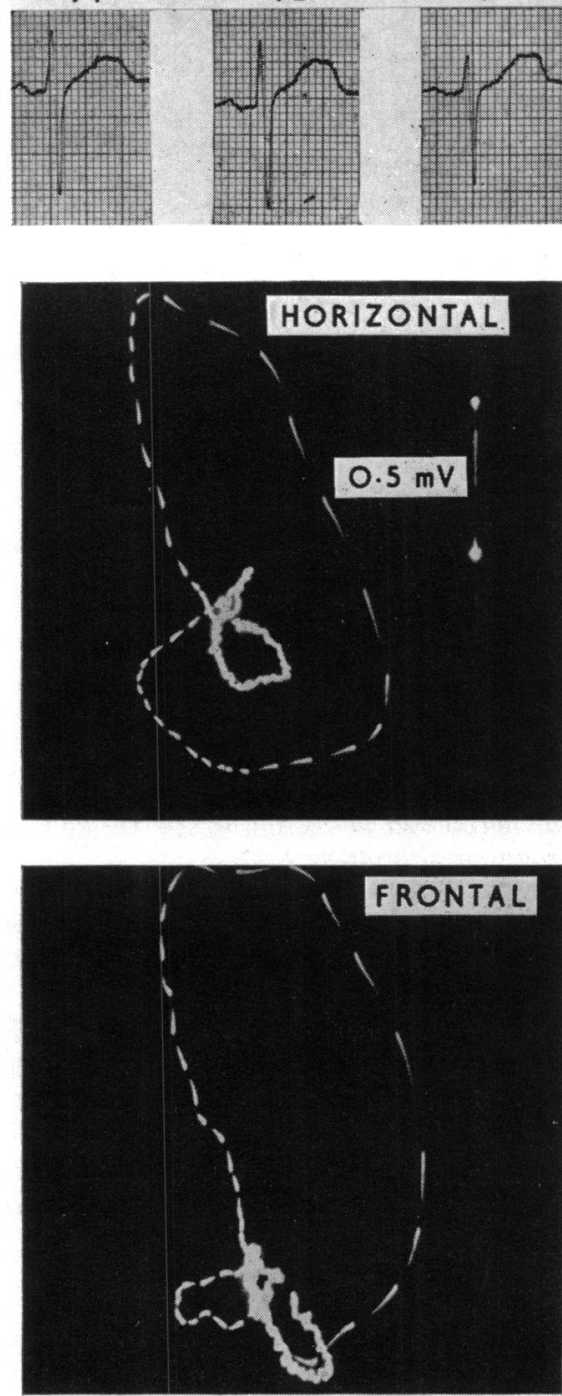

aVR

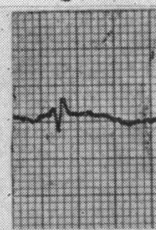

V4
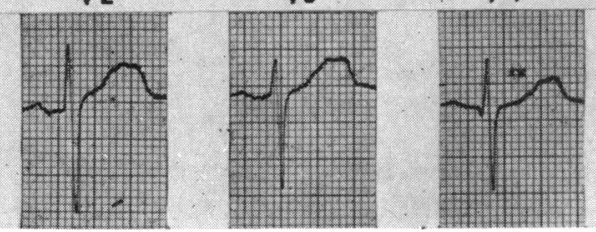

aVL

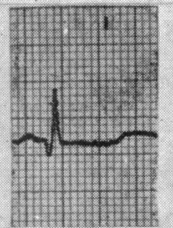

v5
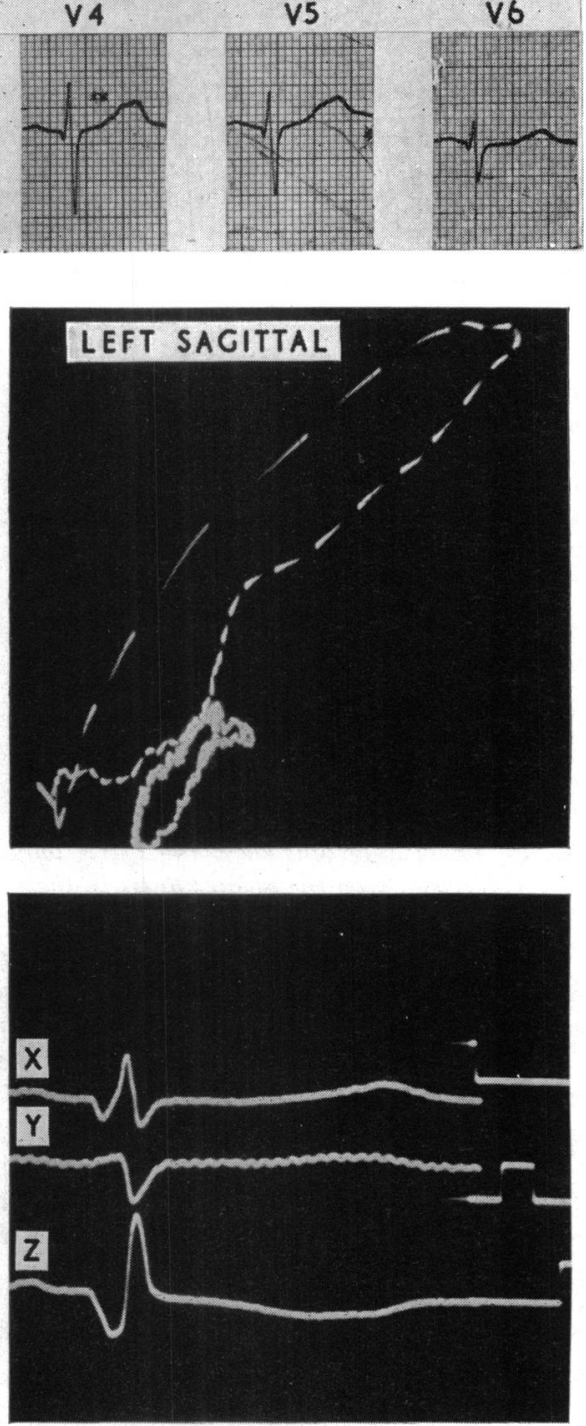

FIG. 4 Isolated lateral infarction. The initial $Q R S$ forces are oriented anteriorly and to the right of the $E$ point in a range greater than $25 \mathrm{msec}$. The corresponding abnormality in the electrocardiogram is a $Q$ wave in leads $D_{I}, a V L$, and V6. However, the main $Q R S$ loop is oriented posteriorly and lead $V I$ shows a ratio $R / S$ less than $I$. 
(a)
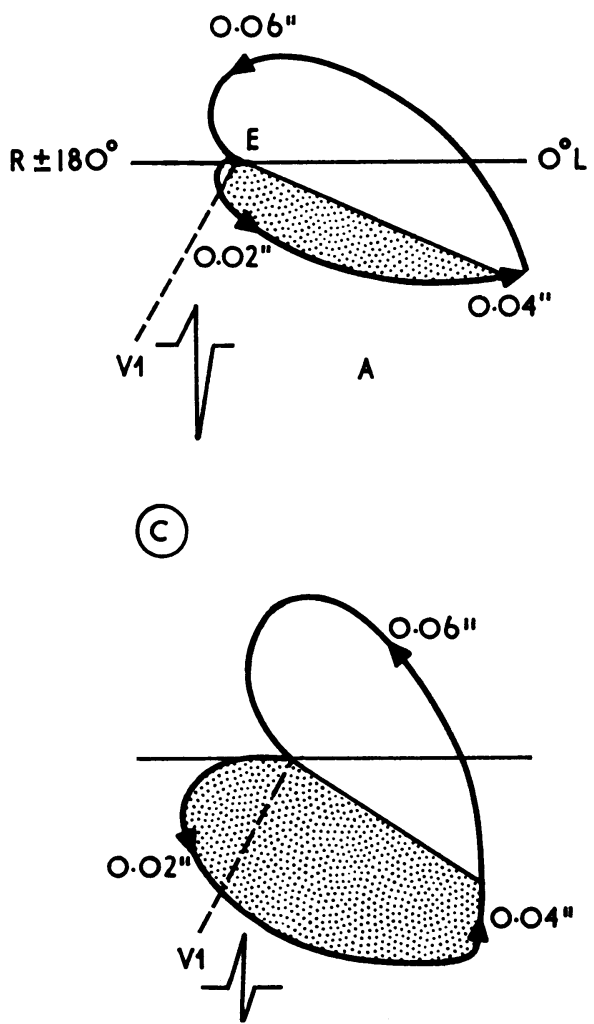

(b)

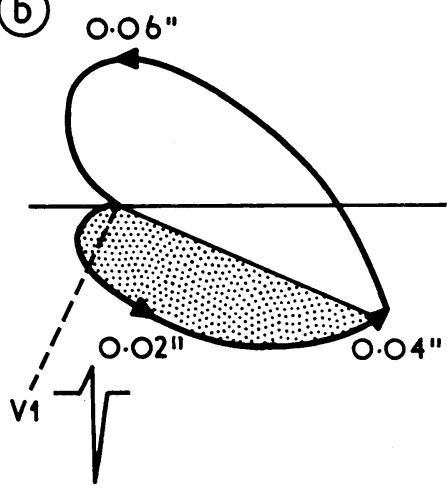

(d)

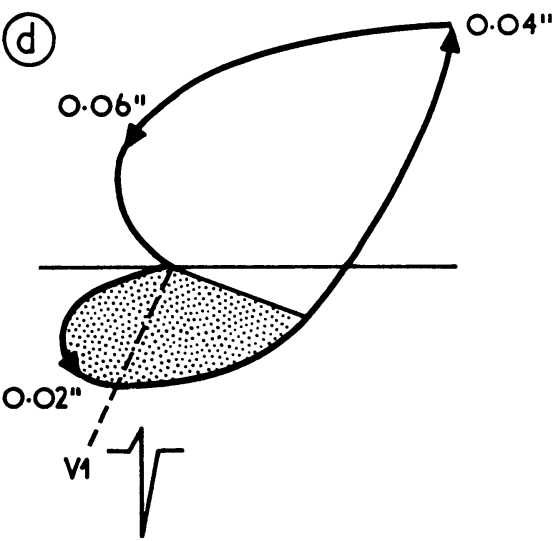

in lead VI. This finding in part agrees with that of Massie and Walsh (1960) that the absence of a ratio $R / S$ greater than I in VI does not exclude the diagnosis of posterior infarction. Closer to our findings were those of Gray et al. who recently (1972), in a study of 31 patients with vectorcardiographic evidence of posterior infarction, found that only $6 \mathrm{had}$ an electrocardiographic ratio $R / S$ greater than $I$ in VI. Moreover, the angiographic study of the left ventricle and coronary arteries of the patients described by Gray et al. (1972) indicated coronary disease and/or asynergy of the posterobasal myocardial wall in I4 patients with a normal electrocardiogram.

The present study also shows that the ratio $R / S$ in $V_{I}$ is less than $I$ in lateral or inferolateral infarction (group IV); it is greater than I in posterolateral infarction (group III). These results suggest 
that the coexistence of posterior and lateral infarction produces the tall $\mathrm{R}$ wave in $\mathrm{VI}$.

In Fig. 5 a probable mechanism of the appearance of the tall $R$ wave in VI after infarction is explained. In posterolateral infarction there is a loss of depolarization forces of the posterior and lateral wall of the left ventricle. Consequently, the QRS loop is displaced anteriorly and rightwards, i.e. in the direction of the praecordial lead Vr. Gray et al. (1972) agree that the tall $R$ wave in VI is due to an orientation of the initial QRS forces anteriorly and to the right as it occurs in lateral infarction.

In our study the greatest displacement of the QRS loop anteriorly and to the right was found in the patients with posterolateral infarction (group III). In the horizontal plane the average vectors of $0.02 \mathrm{sec}$ and $0.04 \mathrm{sec}$ were oriented to $+118^{\circ}$ and $+39^{\circ}$, respectively, and the maximal $Q R S$ vector to $+49^{\circ}$. In addition, the mean values of the maximal anterior voltage and the duration of the anterior QRS forces were $0.80 \mathrm{mV}$ and $57 \mathrm{msec}$, respectively, while the corresponding values of the posterior QRS forces were $0.31 \mathrm{mV}$ and $30.8 \mathrm{msec}$. These values of group III were obviously different from those of the other three groups in which the anterior and rightwards displacement of the QRS loop was not pronounced.

Our findings suggest that the appearance of a tall $R$ wave in VI after myocardial infarction could be explained by the occurrence of two essential changes in ventricular depolarization. Firstly, a pronounced preponderance of anterior over posterior QRS forces; secondly, a displacement of the initial QRS loop forces to the right of the $E$ point exceeding $22 \mathrm{msec}$ in duration. These changes occur in posterolateral infarction.

In true posterior or posteroinferior infarction the relatively small $R$ wave in VI could be explained by a moderate preponderance of the anterior over the posterior QRS forces and a normal duration of the initial forces to the right of the $\mathrm{E}$ point. In addition, in lateral infarction without extension to the posterior wall, the ratio $R / S$ in VI is less than I because the posterior QRS forces are greater than the anterior ones.

In most of the patients with posterior necrosis a delay of the terminal QRS loop forces is usually observed. This delay in the right praecordial leads appears as a slurring of the terminal $30-40 \mathrm{msec}$ of the $S$ deflection (Toutouzas et al., 1969). This phenomenon may be evidence of intraventricular conduction disturbances, which are due to the presence of viable myocardial fibres around (First, Bayley, and Bedford, 1950) or within the infarcted area (Cabrera, Rocha, and Flores, 1959; Durrer, Van Lier, and Büller, 1964).
In conclusion, we believe that the diagnosis of isolated posterior infarction cannot be made solely on the basis of certain electrocardiographic criteria. Conversely, the diagnosis of this infarction can be arrived at in the majority of the patients by the vectorcardiogram. On the other hand, the appearance of a tall $R$ wave or a ratio $R / S$ greater than $I$ in lead VI seems to be a more frequent finding in posterolateral infarction.

We wish to thank Professor J. P. Shillingford for allowing us to use data from ro of his patients in this study.

\section{References}

Cabrera, E., Rocha, J. C., and Flores, G. (1959). El vectorcardiograma de los infarctos miocardicos contrastoruos en la conduction intraventricular. Archivos del Instituto de Cardiología de México, 29, 625.

Chou, T. C., and Helm, R. A. (1967). Clinical Vectorcardiography. Grune and Stratton, New York and London.

Durrer, D., Van Lier, A. A. W., and Büller, J. (1964). Epicardial and intramural excitation in chronic myocardial infarction. American Heart fournal, 68, 765.

Elek, S. R., Allenstein, B. J., Kornbluth, A. W., Griffith, G. C., and Levinson, D. C. (1954). The spatial vectorcardiogram in myocardial infarction typified by prominent $R$ waves in leads $\mathrm{aVr}$ and VI. American Heart fournal, 47, 477.

First, S. R., Bayley, R. H., and Bedford, D. R. (1950). Periinfarction block; electrocardiographic abnormality occasionally resembling bundle branch block and local ventricular block of other types. Circulation, 2, 3 I.

Frank, E. (1956). An accurate, clinically practical system for spatial vectorcardiography. Circulation, 13, 737.

Friedberg, C. (1966). Diseases of the Heart, 3rd ed. W. B. Saunders, Philadelphia and London.

Goldberger, E. (1953). Unipolar Lead Electrocardiography and Vectorcardiography, 3rd ed. Lea and Febiger, Philadelphia.

Gray, W., Corbin, M., King, J., and Dunn, M. (1972). Diagnostic value of vectorcardiogram in strictly posterior infarction. British Heart fournal, 34, 1163.

Gunnar, R. M., Pietras, R. J., Blackaller, J., Dadmun, S. E., Szanto, P. B., and Tobin, J. R., Jr. (1967). Correlation of vectorcardiographic criteria for myocardial infarction with autopsy findings. Circulation, 35, 158.

Gunnar, R. M., Winslow, E. B., Cabin, G., Pietras, R., Rosewell, J., and Szanto, R. (1970). Autopsy correlation of vectorcardiographic criteria for the diagnosis of myocardial infarction. In Proceedings of the XI International Symposium on Vectorcardiography, New York. Sponsored by the Long Island Jewish Medical Center.

Hoffman, I., Taylor, R. C., Morris, M. H., and Kittell, I. (1965). Quantitative criteria for the diagnosis of dorsal infarction using the Frank vectorcardiogram. American Heart fournal, 70, 295.

Hugenholtz, P. G., Forkner, C. E., and Levine, H. D. (I961). A clinical appraisal of the vectorcardiogram in myocardial infarction. II. The Frank system. Circulation, 24, 825.

Hurst, J. W., and Logue, R. B. (1970). The Heart, 2nd ed. McGraw-Hill, New York.

Levy, L., Jacobs, H. J., Chastant, H. P., and Strauss, H. B. (1950). Prominent $R$ wave and shallow $S$ wave in lead $V_{1}$ as a result of lateral myocardial infarction. American Heart Fournal, 40, 447.

Lipman, B. S., and Massie, E. (1965). Clinical Scalar Electro- 
cardiography, 5th ed. Year Book Medical Publishers, Chicago.

Massie, E., and Walsh, T. J. (1960). Clinical Vectorcardiography and Electrocardiography. The Year Book Publishers, Chicago.

Myers, G. B., and Oren, B. G. (1945). The use of the augmented unipolar left leg lead in the differentiation of the normal from abnormal $Q$ wave in standard lead III. Fournal of Laboratory and Clinical Medicine, 30, 347.

Perloff, J. K. (1964). The recognition of strictly myocardial infarction by conventional scalar electrocardiography. Circulation, 30, 706 .

Pruitt, R. D., Dennis, E. W., and Kinard, S. A. (1963). The difficult electrocardiographic diagnosis of myocardial infarction. Progress in Cardiovascular Diseases, 6, 85.

Tandowsky, R. M. (1968). The Oscillometric Vectorcardiogram. C. Thomas, Springfield, Illinois.

Toutouzas, P., Hubner, P., Sainani, G., and Shillingford, J. (1969). Value of vectorcardiogram in diagnosis of posterior and inferior myocardial infarctions. British Heart fournal, 31, 629.
Tranchesi, J., Texeira, V., Ebaid, M., Boccalandro, I., Bocanegra, J., and Pileggi, F. (I96I). The vectorcardiogram in dorsal or posterior myocardial infarction. American fournal of Cardiology, 7, 505 .

Tulloch, J. A. (1952). The electrocardiographic features of high posterolateral myocardial infarction. British Heart fournal, I4, 379.

Walsh, T. J., Tiongson, P. M., Stoddard, E. A., and Massie, E. (1962). The vectorcardiographic QRSsE-loop findings in inferoposterior myocardial infarction. American Heart Fournal, 63, 416.

World Health Organization (1959). Hypertension and Coronary Heart Disease: Classification and Criteria for Epidemiological Studies. First report of the Expert Committee on Cardiovascular Diseases and Hypertension. Technical Report Series, No. 168. World Health Organization, Geneva.

Requests for reprints to Dr. Pavlos Toutouzas, ro Likiou Street, Athens 138, Greece. 